\title{
Antibacterial activities of selected edible plants extracts against multidrug-resistant Gram-negative bacteria
}

\author{
Doriane E Djeussi ${ }^{1}$, Jaurès AK Noumedem¹, Jackson A Seukep', Aimé G Fankam¹, Igor K Voukeng1', \\ Simplice B Tankeo', Antoine HL Nkuete ${ }^{2}$ and Victor Kuete ${ }^{1 *}$
}

\begin{abstract}
Background: In response to the propagation of bacteria resistant to many antibiotics also called multi-drug resistant (MDR) bacteria, the discovery of new and more efficient antibacterial agents is primordial. The present study was aimed at evaluating the antibacterial activities of seven Cameroonian dietary plants (Adansonia digitata, Aframomum alboviolaceum, Aframomum polyanthum, Anonidium. mannii, Hibiscus sabdarifa, Ocimum gratissimum and Tamarindus indica).

Methods: The phytochemical screening of the studied extracts was performed using described methods whilst the liquid broth micro dilution was used for all antimicrobial assays against 27 Gram-negative bacteria.

Results: The results of the phytochemical tests indicate that all tested extracts contained phenols and triterpenes, other classes of chemicals being selectively present. The studied extracts displayed various degrees of antibacterial activities. The extracts of A. digitata, H. sabdarifa, A. polyanthum, A. alboviolaceum and O. gratissimum showed the best spectra of activity, their inhibitory effects being recorded against $81.48 \%, 66.66 \%, 62.96 \%, 55.55 \%$, and $55.55 \%$ of the 27 tested bacteria respectively. The extract of A. polyanthum was very active against E. aerogenes EA294 with the lowest recorded minimal inhibitory concentration (MIC) of $32 \mu \mathrm{g} / \mathrm{ml}$.

Conclusion: The results of the present work provide useful baseline information for the potential use of the studied edible plants in the fight against both sensitive and MDR phenotypes.
\end{abstract}

Keywords: Antibacterial, Multi-drug resistant bacteria, Dietary plants

\section{Background}

Pathogenic bacteria have always been considered as a major cause of morbidity and mortality in humans. Even though pharmaceutical companies have produced a number of new antibacterials in the last years, resistance to these drugs has increased and has now became a global concern [1]. The global emergence of multi-drug resistant (MDR) bacteria is increasingly limiting the effectiveness of current drugs and significantly causing treatment failure [2]. Bacterial resistance to chemically unrelated antimicrobial agents is public health concern [3] and may be caused by over-expression of MDR efflux pumps [4]. In Gram-

\footnotetext{
* Correspondence: kuetevictor@yahoo.fr

'Department of Biochemistry, Faculty of Science, University of Dschang, Dschang, Cameroon

Full list of author information is available at the end of the article
}

negative bacteria, the effect of the efflux pumps in combination with the reduced drug uptake (due to the presence of a double membrane barrier) is responsible for the high inherent and acquired antibiotic resistance often associated with this group of organisms [5]. Among Gramnegative bacteria, many of these MDR efflux pumps belong to the RND (resistance-nodulation-cell division) type family of tripartite efflux pumps.

Due to the increase of resistance to antibiotics, there is a pressing need to develop new and innovative antimicrobial agents. Among the potential sources of new agents, plants have long been investigated. Because, they contain many bioactive compounds that can be of interest in therapeutic. Because of their low toxicity, there is a long tradition of using dietary plants in the treatment of infectious disease in Cameroonian folk medicine. 
Consequently, we focused one of the objective of our research group at investigating the antibacterial potentials of such plants against MDR phenotypes. In previous studies we demonstrated the antimicrobial activity of many Cameroonian dietary plants against MDR bacteria [6-9]. In our continuous search of the antibacterial activities of Cameroonian edible plants, we designed the present work to determine the activity of seven selected Cameroonian dietary plants (Adansonia digitata, Aframomum alboviolaceum, Aframomum polyanthum, Anonidium mannii, Hibiscus sabdarifa, Ocimum gratissimum and Tamarindus indica) against MDR Gramnegative bacteria.

\section{Methods}

\section{Plant materials and extraction}

The herbal sample consisted of seven different Cameroonian dietary plants namely the leaves of Adansonia digitata and Anonidium mannii, the rhizomes of Aframomum alboviolaceum, Aframomum polyanthum, the whole plants of Hibiscus sabdarifa and Ocimum gratissimum, and the fruits of Tamarindus indica. The plants were purchased from markets in the West region of Cameroon in January 2011. They were further identified at the National Herbarium (Yaoundé, Cameroon) where the voucher specimens were deposited under reference numbers (Table 1). Each plant was dried at room temperature and the powdered material was then weighed (300 g), soaked in $1 \mathrm{~L}$ of methanol $(\mathrm{MeOH})$ for $48 \mathrm{~h}$ and filtered using Whattman $\mathrm{N}^{\circ} 1$ filter paper. The filtrate obtained was concentrated under reduced pressure (at $68^{\circ} \mathrm{C}$ ) in a rotary evaporator to obtain the crude extract. The crude extracts were kept at $4^{\circ} \mathrm{C}$ until further uses.

\section{Preliminary phytochemical screening}

The plant materials were screened for the presence of different classes of secondary metabolites including alkaloids, flavonoids, phenols, saponins, tannins, anthocyanins, anthraquinones, sterols, and triterpenes using previously described methods [34].

\section{Bacterial susceptibility determinations}

The minimal inhibitory concentrations (MICs) of the seven plant extracts were determined using a rapid $p$ Iodonitrotetrazolium chloride (INT; Sigma-Aldrich, St Quentin Fallavier, France) colorimetric assay $[35,36]$. Briefly, the test samples were first dissolved in dimethylsulfoxide (DMSO, Sigma-Aldrich)-Mueller Hinton Broth (MHB; Sigma-Aldrich). The solution obtained was then added to MHB and serially diluted two fold (in a 96-well microtilter plate). One hundred microliters of inoculums (1.5x $10^{6} \mathrm{CFU} / \mathrm{ml}$ ) prepared in MHB were then added. The plates were covered with a sterile plate sealer and then agitated with a shaker to mix the contents of the wells and incubated at $37^{\circ} \mathrm{C}$ for $18 \mathrm{~h}$. The final concentration of DMSO was less than $2.5 \%$, and thus did not affect the microbial growth. Wells containing MHB, $100 \mu \mathrm{l}$ of inoculum, and DMSO at a final concentration of $2.5 \%$ served as the negative control (this internal control with DMSO $2.5 \%$ was systematically added). Chloramphenicol (SigmaAldrich) was used as reference antibiotic. The MICs of each extract were detected after $18 \mathrm{~h}$ of incubation at $37^{\circ} \mathrm{C}$ following addition of $40 \mu \mathrm{l} \mathrm{INT}(0.2 \mathrm{mg} / \mathrm{ml})$ and incubation at $37^{\circ} \mathrm{C}$ for $30 \mathrm{~min}$. Viable bacteria reduced this yellow dye to pink. The MIC of each sample was defined as its lowest concentration that prevented this change and then resulted in the complete inhibition of microbial growth. The Minimum Bactericidal Concentration (MBC) was determined by sub-culturing samples from the wells with concentrations above the MIC on new plates of Mueller Hinton broth (MHB). The MBC was considered as the lowest concentration of the extract associated with no bacterial culture.

Each assay was performed three independent times in triplicate. In case where they were different, the MIC or $\mathrm{MBC}$ were taken as the most frequently occurring values. Chloramphenicol was tested alone and in the presence of Phenylalanine arginine- $\beta$-naphtylamide (PAßN) at a final concentration of $30 \mu \mathrm{g} / \mathrm{ml}$, as described previously [37].

\section{Results}

\section{Phytochemical analysis}

Freshly prepared extracts were subjected to a preliminary phytochemical screening for various constituents. The results (Table 2) revealed the presence of phenols, polyphenols and triterpenes. Anthraquinones were not detected in any of the extracts while anthocyanins were found only in the extracts of the genus Aframomum (A. alboviolaceum and A. polyanthum).

\section{Antibacterial activity of the plant extracts}

The antibacterial activity of the plant extracts are depicted in Table 3. The results indicated that the plants extracts showed antibacterial activities at variable degrees against MDR bacteria, with MICs values varying from 32 to $1024 \mu \mathrm{g} / \mathrm{ml}$. Extracts of $A$. digitata displayed the most important spectrum of activity, its inhibitory effects being observed against $81.48 \%$ of the bacterial strains, followed by the extracts of $H$. sabdarifa (66.66\%), A. polyanthum (62.96\%), A. alboviolaceum (55.55\%) and O. gratissimum (55.55\%). The extract of A. polyanthum showed the highest activity against E. aerogenes EA294 with a MIC value of $32 \mu \mathrm{g} / \mathrm{ml}$. The extracts of $T$. indica and $A$. mannii did not show antibacterial activity against the majority of the bacteria tested, their inhibitory effect being noted against $6 / 27(22.22 \%)$ and $7 / 27(25.92 \%)$ bacterial strains tested respectively. The microorganisms of the species P. aeruginosa (PA01 and PA124), known for 
Table 1 Information on the plants used and report on evidence of their activities

\begin{tabular}{|c|c|c|c|c|}
\hline $\begin{array}{l}\text { Species (family); Voucher } \\
\text { number* }\end{array}$ & Traditional uses & Parts used traditionally & $\begin{array}{l}\text { Bioactive or potentially bioactive } \\
\text { components }\end{array}$ & Bioactivities \\
\hline $\begin{array}{l}\text { Adansonia digitata (Malvaceae); } \\
42417 / \mathrm{HNC}\end{array}$ & $\begin{array}{l}\text { Analgesic, anti-diarrheal, smallpox, } \\
\text { rubella [10], antipyretic, fever, dysenteria, } \\
\text { anti-inflammatory, astringent [11] }\end{array}$ & Pulps, Fruits, leaves, Pip, Bark & / & $\begin{array}{l}\text { Ethanol and aqueous extract: Ec [12] } \\
\mathrm{Sa}, \mathrm{Se}, \mathrm{STm}, \mathrm{Pa}[13] ;[14,15] \mathrm{Hs}[11] .\end{array}$ \\
\hline $\begin{array}{l}\text { Aframomum alboviolaceum } \\
\text { (Zingiberaceae); } 34888 / \mathrm{HNC}\end{array}$ & Diuretic, anthelmintic, fever, antiparasitic [16]. & Roots & $\begin{array}{l}\text { Methyl (E)-14Ksi,15-epoxylabd-8(17), } \\
\text { 12-dien-16-oate; (E)-labda-8(17),12-diene-15,16-dial } \\
\text { and (E)-8beta,17-epoxylabd-12-ene-15,16-dial [17] }\end{array}$ & HC [18]. \\
\hline $\begin{array}{l}\text { Aframomum polyanthum } \\
\text { (Zingiberaceae) } 3981 / S R F K\end{array}$ & / & Fruits & Aframodial [19]. & Sa, Scp, Ha, Cu [19]. \\
\hline \multirow{3}{*}{$\begin{array}{l}\text { Anonidium mannii (Annonaceae); } \\
\text { 1918/SRFK }\end{array}$} & \multirow{3}{*}{$\begin{array}{l}\text { Spider and snake bites, bronchitis, } \\
\text { dysenteria, gastroenteritis [20], syphilis, } \\
\text { [21]; diarrhea, malaria [22]. }\end{array}$} & Stem & \multirow[t]{3}{*}{ Prenylatedbisindole [23]. } & \multirow[t]{3}{*}{ / } \\
\hline & & Bark & & \\
\hline & & Leaves & & \\
\hline $\begin{array}{l}\text { Hibiscus sabdarifa (Malvaceae); } \\
\text { 42795/HNC }\end{array}$ & $\begin{array}{l}\text { Diuretic, stomachic, laxative, aphrodisiac, } \\
\text { antiseptic, astringent, cholagogue, sedative, } \\
\text { hypertension and other cardiac diseases [24]. }\end{array}$ & Flowers & Protocatechic acid, [25]; [26], hydroxycitricacid. & $\begin{array}{l}\text { Ethanol, methanol and aqueous extracts: } \\
\mathrm{Ec}, \mathrm{Pa}, \mathrm{Kp}, \mathrm{Hi}, \mathrm{Sa}, \mathrm{Spy}, \mathrm{Sp},[27] \text {. Methanolic } \\
\text { extract: Bs, Ml, Sm, Cs, Bc [24]. }\end{array}$ \\
\hline $\begin{array}{l}\text { Ocimum gratissimum (Lamiaceae); } \\
42738 / \mathrm{HNC}\end{array}$ & $\begin{array}{l}\text { Respiratory tracts diseases, diarrhea, } \\
\text { anti-hypertensive, malaria [28]. }\end{array}$ & leaves, Roots, Buds & $\begin{array}{l}\text { ( } \beta \text {-caryophyllene,y-terpinène, (Z)-a-bisabolene, } \\
\text { thymol, p-cymene, eugenol, limonène, } \\
\text { a-terpinolene, a-terpinéol [29]. }\end{array}$ & $\begin{array}{l}\text { Essential oil: Af, AB }, \text { Hc [30] Ethanol } \\
\text { extract: Ec, Sa [31]. }\end{array}$ \\
\hline $\begin{array}{l}\text { Tamarindus indica } \\
\text { (Caesalpiniaceae); 26326/SRFC }\end{array}$ & $\begin{array}{l}\text { Fever, gastric ulcer, diarrhea, jaundice [32], } \\
\text { conjunctivitis, hemorrhoid, astringent, } \\
\text { asthma, eye inflammation [33]. }\end{array}$ & Fruits Bark & / & Ethanol and aqueous extracts: Ec [12] \\
\hline
\end{tabular}


Table 2 Parts used, extraction yields, and phytochemical composition of the plant extracts

\begin{tabular}{|c|c|c|c|c|c|c|c|}
\hline Extracts & A. digitata & A. alboviolaceum & A. polyanthum & A. mannii & H. sabdarifa & O. gratissimum & T. indica \\
\hline Parts used & Leaves & Fruits & Fruits & Leaves & Twigs & Twigs & Fruits \\
\hline Yield* (\%) & 12.17 & 6.45 & 3.23 & 3.39 & 4.94 & 4.75 & 37.98 \\
\hline Alkaloids & - & + & - & + & + & + & + \\
\hline Anthocyanines & - & + & + & - & - & - & - \\
\hline Anthraquinones & - & - & - & - & - & - & - \\
\hline Flavonoids & - & + & - & - & + & - & + \\
\hline Phenols & + & + & + & + & + & + & + \\
\hline Polyphenols & + & + & + & + & + & + & + \\
\hline Saponines & + & - & + & + & + & - & + \\
\hline Tannins & + & - & - & + & - & + & - \\
\hline Sterols & + & - & - & + & + & + & + \\
\hline Triterpenes & + & + & + & + & + & + & + \\
\hline
\end{tabular}

(+): Present; (-): Absent; ${ }^{~}$ yield calculated as the ratio of the mass of the obtained methanol extract/mass of the plant powder.

their multi-resistance to drugs, were resistant to all the plant extracts tested in this work (with MIC $>1024 \mu \mathrm{g} / \mathrm{ml}$ ).

Some of the studied extracts showed bactericidal effects on few numbers of bacteria. These effects were observed with the crude extracts of $A$. digitata, against E. coli MC4100 and K. pneumoniae KP55 with the ratios minimal bactericidal versus minimal inhibitory concentrations $(\mathrm{MBC} / \mathrm{MIC})$ equal to 1 and 2 respectively. For A. polyanthum's extract, the ratio $\mathrm{MBC} / \mathrm{MIC}$ was equal to 2 on K. pneumoniae KP55. O. gratissimum also showed ratios MBC/MIC equal to 1 on E. coli AG 102. The crude extract of $H$. sabdarifa was also bactericidal against $E$. coli MC4100 and W3110 and against E. cloacae BM67 with the ratio equal to $1 ; 1$ and 4 respectively. Chloramphenicol used as reference antibiotic showed variable inhibitory activity on different strains of bacteria with MIC values ranging from 2 to $512 \mu \mathrm{g} / \mathrm{ml}$. These activities of chloramphenicol was bacteristatic on the majority of bacteria $(\mathrm{MBC} / \mathrm{MIC}>4)$ and in some cases, its MICs were equal to those obtained with some plant extracts $(A$. digitata on K. pneumoniae KP55, H. sabdarifa on E. cloacae BM 67 and O. gratissinum on E. cloacae ECCI69).

\section{Discussion}

Each of the extract tested in the present study displayed antibacterial activity on at least 6 of 27 bacterial strains tested. However differences were observed between antibacterial activities of the extracts. These differences could be due to the differences in the chemical composition of these extracts as the secondary metabolites of plants have many effects including antibacterial and antiviral properties $[9,38]$. The overall data of this study were in accordance with previous results. Apart from the phytochemicals found in A. digitata extract, previous studies showed the presence of an alkaloid namely adansonin [15]. The antibacterial activity of the aqueous and ethanol extracts of this plant has already been reported against E. coli [12]. Therefore, the inhibitory activity found herein against reference and multi-resistant strains of $E$. coli as well as other Gram-negative species is complementary to Yagoub's [12] report.

Phytochemical screening results of $H$. sabdarifa was in accordance with the results previously obtained [24]. This latter suggested that the presence of alkaloids (which interfere with cell division) in H. sabdariffa could account for its antimicrobial activity. They demonstrated that methanol extract of $H$. sabdarifa possess inhibitory activities against E. coli, P. aeruginosa and S. aureus. In this report, the antibacterial activity was not observed against $P$. aeruginosa, but the results obtained herein are not in contradiction with those previously reported since the previous MIC of $1300 \mu \mathrm{g} / \mathrm{ml}$ was higher than the highest concentration used in this work. The results of the present work also bring additional data on the antibacterial activity of $H$. sabdarifa, since we report for the first time its activity against $E$. aerogenes, $P$. stuartii and K. pneumoniae.

To the best of our knowledge, phytochemical composition of A. alboviolaceum and A. polyanthum is described here for the first time. The different phytochemicals found here should then explain its antibacterial activity against different bacterial strains tested. The plants of the genus Aframomum was already found to possess flavonoids, diterpenoids and arylalkaloids which could explain their antibacterial activity [39].

All the phytochemical constituent found in the extract of $O$. gratissinum was previously reported by Akinmoladun et al. [40] who also found flavonoids in the same extract. Nevertheless, the antibacterial activity of this extract is in agreement with the findings of Obinna et al. [31] who showed the inhibitory activity of $O$. gratissimum against E. coli and S. aureus. Moreover the present work brings 
Table 3 Minimal inhibitory concentration (MIC), minimal bactericidal (MBC) and MBC/MIC ratios of the plant extracts and CHL on the studied bacterial species Bacteria Extracts and et antimicrobial parameters (MIC et MBC in $\mu \mathrm{g} / \mathrm{ml}$ )

\begin{tabular}{|c|c|c|c|c|c|c|c|c|c|c|c|c|c|}
\hline & & \multicolumn{12}{|c|}{ Extracts and et antimicroblal parameters (IVIC et IVISC in $\mu \mathrm{g} / \mathrm{mI}$ ) } \\
\hline & & \multicolumn{3}{|c|}{ Adansonnia digitata } & \multicolumn{3}{|c|}{ Aframomum alboviolaceum } & \multicolumn{3}{|c|}{ Aframomum polyanthum } & \multicolumn{3}{|c|}{ Anonidium mannii } \\
\hline & & MIC & MBC & $\mathrm{MBC} / \mathrm{MIC}$ & MIC & MBC & $\mathrm{MBC} / \mathrm{MIC}$ & MIC & MBC & $\mathrm{MBC} / \mathrm{MIC}$ & MIC & MBC & $\mathrm{MBC} / \mathrm{MIC}$ \\
\hline \multirow[t]{8}{*}{ E. coli } & ATCC8739 & 1024 & - & - & - & - & - & 1024 & - & - & - & - & - \\
\hline & ATCC10536 & - & - & - & - & - & - & 512 & - & & - & - & - \\
\hline & AG100 & 512 & - & - & 1024 & - & - & - & - & - & - & - & - \\
\hline & AG100A & 128 & - & - & 1024 & - & - & - & - & - & - & - & - \\
\hline & $\mathrm{AG} 100 \mathrm{~A}_{\mathrm{TET}}$ & 1024 & - & - & 256 & - & - & 1024 & - & - & 1024 & - & - \\
\hline & AG102 & 256 & 512 & 2 & 1024 & - & - & 512 & - & - & - & - & - \\
\hline & MC4100 & 1024 & 1024 & 1 & 1024 & - & - & - & - & - & 512 & - & - \\
\hline & W3110 & 512 & - & - & - & - & - & 512 & - & - & - & - & - \\
\hline \multirow[t]{6}{*}{ E.aerogenes } & ATCC13048 & 128 & 512 & 4 & 512 & - & - & - & - & - & - & - & - \\
\hline & CM64 & 1024 & - & - & - & - & - & 1024 & - & - & - & - & - \\
\hline & EA27 & - & - & - & 1024 & - & - & - & - & - & 1024 & - & - \\
\hline & EA289 & 512 & - & - & 1024 & - & - & 1024 & - & - & 1024 & - & - \\
\hline & EA298 & 1024 & 1024 & 1 & - & - & - & 1024 & - & - & - & - & - \\
\hline & EA294 & 1024 & - & - & 256 & - & - & 32 & 512 & 16 & - & - & - \\
\hline \multirow[t]{3}{*}{ E. cloacae } & ECCl69 & 512 & - & - & - & - & - & 1024 & - & - & 1024 & - & - \\
\hline & BM47 & 1024 & - & - & - & - & - & 1024 & & - & - & - & - \\
\hline & BM67 & 1024 & - & - & 1024 & & - & 512 & - & - & 1024 & - & - \\
\hline \multirow[t]{5}{*}{ K. Pneumonia } & ATCC11296 & 512 & - & - & - & - & - & 256 & 1024 & 4 & - & - & - \\
\hline & KP55 & 128 & 256 & 2 & 512 & 1024 & 2 & - & - & - & - & - & - \\
\hline & KP63 & 1024 & - & - & 1024 & - & - & - & - & - & - & - & - \\
\hline & K24 & 512 & - & - & 512 & - & - & 1024 & - & - & - & - & - \\
\hline & K2 & 1024 & - & - & 512 & - & - & 1024 & - & - & 1024 & - & - \\
\hline \multirow[t]{3}{*}{ P. Stuartii } & ATCC29914 & - & - & - & - & - & - & 512 & - & - & - & - & \\
\hline & PS2636 & 1024 & - & - & 1024 & - & - & 1024 & - & - & - & - & - \\
\hline & PS299645 & 1024 & - & - & - & - & - & - & - & - & - & - & - \\
\hline \multirow[t]{2}{*}{ P. aeru-ginosa } & PA01 & - & - & - & - & - & - & - & - & - & - & - & - \\
\hline & PA124 & - & - & - & - & - & - & - & - & - & - & - & - \\
\hline
\end{tabular}


Table 3 Minimal inhibitory concentration (MIC), minimal bactericidal (MBC) and MBC/MIC ratios of the plant extracts and CHL on the studied bacterial species (Continued)

\begin{tabular}{|c|c|c|c|c|c|c|c|c|c|c|c|c|c|}
\hline \multirow[t]{2}{*}{ Bacteria } & & \multicolumn{3}{|c|}{ Hibiscus sabdarifa } & \multicolumn{3}{|c|}{ Ocimum gratissimum } & \multicolumn{3}{|c|}{ Tamarintus indica } & \multicolumn{3}{|c|}{ Chloramphenicol* } \\
\hline & & $\overline{\mathrm{MIC}}$ & MBC & $\overline{M B C / M I C}$ & MIC & MBC & $\overline{M B C / M I C}$ & MIC & MBC & $\overline{M B C / M I C}$ & MIC & MBC & $\overline{M B C / M I C}$ \\
\hline \multirow[t]{8}{*}{$\overline{E \text { E. coli }}$} & ATCC8739 & - & - & - & 512 & - & - & - & - & - & 4 & - & - \\
\hline & ATCC10536 & - & - & - & 1024 & - & - & - & - & - & 2 & 128 & 64 \\
\hline & AG100 & 1024 & - & - & - & - & - & - & - & - & $4(2)$ & $256(32)$ & $64(16)$ \\
\hline & AG100A & 512 & - & - & - & - & - & - & - & - & 2 & 64 & 32 \\
\hline & AG100A $A_{T E T}$ & 1024 & - & - & - & - & - & - & - & - & $64(8)$ & $256(64)$ & $4(8)$ \\
\hline & AG102 & 1024 & - & - & 1024 & 1024 & 1 & - & - & - & 8 & - & - \\
\hline & MC4100 & 1024 & 1024 & 1 & 512 & - & - & 1024 & - & - & 64 & - & - \\
\hline & W3110 & 1024 & 1024 & 1 & - & - & - & 512 & - & - & 4 & 32 & 8 \\
\hline \multirow[t]{6}{*}{ E.aerogenes } & ATCC13048 & 1024 & - & - & 1024 & - & - & - & - & - & 8 & 128 & 16 \\
\hline & CM64 & 1024 & - & - & 1024 & - & - & - & - & - & $256(64)$ & $-(64)$ & $-(1)$ \\
\hline & EA27 & 1024 & - & - & - & - & - & - & - & - & $256(32)$ & $512(256)$ & $2(8)$ \\
\hline & EA289 & 1024 & - & - & 512 & - & - & - & - & - & $512(32)$ & $512(128)$ & $1(4)$ \\
\hline & EA298 & 512 & - & - & 512 & - & - & 1024 & 1024 & 1 & $128(64)$ & $-(64)$ & $-(1)$ \\
\hline & EA294 & 1024 & - & - & 1024 & - & - & - & - & - & 4 & 16 & 4 \\
\hline \multirow[t]{3}{*}{ E. cloacae } & ECCl69 & - & - & - & 512 & - & - & 1024 & - & - & 512 & - & - \\
\hline & BM47 & - & - & - & - & - & - & - & - & - & 512 & - & - \\
\hline & BM67 & 256 & 1024 & 4 & - & - & - & 1024 & - & - & 256 & - & - \\
\hline \multirow[t]{5}{*}{ K. Pneumonia } & ATCC11296 & 1024 & - & - & 1024 & - & - & - & - & - & 4 & 512 & 128 \\
\hline & KP55 & 512 & - & - & 512 & - & - & - & - & - & 128 & 128 & 1 \\
\hline & KP63 & - & - & - & 1024 & - & - & - & - & - & $64(16)$ & $-(256)$ & $-(16)$ \\
\hline & K24 & 1024 & - & - & 1024 & - & - & - & - & - & $16(1)$ & $-(64)$ & $-(64)$ \\
\hline & K2 & 512 & - & - & - & - & - & 1024 & - & . & 32 & - & - \\
\hline \multirow[t]{3}{*}{ P. Stuartii } & ATCC29914 & - & - & - & - & - & - & - & - & - & 8 & 128 & 16 \\
\hline & PS2636 & - & - & - & 128 & & - & - & - & - & 32 & 256 & 8 \\
\hline & PS299645 & 512 & - & - & - & - & - & - & - & - & 16 & 512 & 32 \\
\hline \multirow[t]{2}{*}{ P. aeru-ginosa } & PA01 & - & - & - & - & - & - & - & - & - & $16(8)$ & $-(256)$ & $-(32)$ \\
\hline & PA124 & - & - & - & - & - & - & - & - & - & $32(16)$ & $-(-)$ & $-(-)$ \\
\hline
\end{tabular}

$(-):>1024 \mu \mathrm{g} / \mathrm{ml}$ for extracts and $>512 \mu \mathrm{g} / \mathrm{ml}$ for chloramphenicol and not calculated for MBC/MIC.

${ }^{*}()$ : for chloramphenicol in the presence of PABN. 
additional information of the antibacterial activities of this plant against multi-resistant bacteria.

Previous reports showed good antibacterial effect of $T$. indica against $E$. coli strains isolated from urine and water samples. Another plant of the present work namely A. manni is used traditionally for treatment of different ailments including different infectious diseases like gastroenteritis and syphilis. PAßN, is a potent inhibitor of the RND efflux systems is especially active on AcrAB-TolC and MexAB-OprM. The wide range enhancement (on all the strains) of the antibacterial activity by $\mathrm{PA} \beta \mathrm{N}$ observed herein with chloramphenicol confirmed that an active efflux system expressed by tested bacteria is responsible for their resistance to chloramphenicol. The wide substrate specificity of these pumps could allow them to provoke extrusion of various active antibacterial compounds, preventing their inhibitory effects [9]. Therefore, the low antibacterial activities of these plants shown in the present work should thus be due to the resistance of bacteria strains tested (see Additional file 1: Table S1). The contrast between high number of secondary metabolite classes found in these extracts reinforces the idea that the detection of the classes of phytochemicals in plants is not a guarantee for a good antibacterial properties [9]. A sample is bactericidal when the ratio $\mathrm{MBC} / \mathrm{MIC} \leq 4$ and bacteriostatic when this ratio is $>4$ [9]. It therefore appeared that bactericidal effects were obtained with the extract from $A$. alboviolaceum, $T$. indica and $O$. gratissimum against 1 of the 27 tested bacterial strains and $A$. digitata against 5/27 (Table). No bactericidal activity was obtained with $A$. mannii extract on all the studied bacteria. This shows that the studied extract mostly exhibited bacteriostatic effects.

\section{Conclusion}

The results of the present study support the traditional use of the studied plants in the treatment of bacterial infections. They also provide an important basis for the use of methanol extract of the edible plants used to control infectious diseases caused by Gram-negative bacteria including MDR strains.

\section{Additional file}

Additional file 1: Table S1. Bacterial strains and features.

\section{Abbreviations}

ATCC: American Type Culture Collection; CFU: Colonies forming unit; CHL: Chloramphenicol; DMSO: Dimethylsulfoxyde; INT: p-iodonitrotetrazolium chloride; MDR: Multidrug Resistant; MHB: Mueller Hinton Broth; MIC: Minimal Inhibitory Concentration; PABN: Phenylalanine Arginine B-Naphthylamide; RND: Resistance Nodulation-cell Division.

\section{Competing interests}

The authors declare that they have no competing interest.

\section{Authors' contributions}

DED, JAKN, AGF, IKV, SBT, AHLN and AJS carried out the study; VK designed the experiments, supervised the work; JAKN and VK wrote the manuscript; VK provided the bacterial strains; All authors read and approved the final manuscript.

\section{Acknowledgements}

Authors are thankful to Pr Jean-Marie Pagès for Chair of the UMR-MD1 Unit, Université de la Méditerranée, France for his support to afford MDR bacteria, the Cameroon National Herbarium (Yaounde) for plants identification and Mr Elvis Ndzukong for language editing.

\section{Author details}

${ }^{1}$ Department of Biochemistry, Faculty of Science, University of Dschang, Dschang, Cameroon. 'Department of Organic Chemistry, Faculty of Science, University of Dschang, Dschang, Cameroon.

Received: 22 March 2013 Accepted: 8 July 2013

Published: 10 July 2013

\section{References}

1. Adwan G, Mhanna M: Synergistic effects of plant extracts and antibiotics on staphylococcus aureus strains isolated from clinical specimens. Journal of Scientific Research 2008, 3:134-139.

2. Hancock EW: Mechanisms of action of newer antibiotics for Gram-positive pathogens. Lancet Infect Dis 2005, 5:209-218.

3. Sharma R, Sharma CL, Kapoor B: Antibacterial resistance: current problems and possible solutions. Indian J Med Sci 2005, 59:120-129.

4. Li XZ, Nikaido H: Efflux-mediated drug resistance in bacteria. Drugs 2004, 64:159-204.

5. Lomovskaya O, Bostian KA: Practical applications and feasibility of efflux pump inhibitors in the clinic-a vision for applied use. Biochem Pharmacol 2006, 71:910-918.

6. Fankam A, Kuete V, Voukeng I, Kuiate J, Pages J-M: Antibacterial activities of selected Cameroonian spices and their synergistic effects with antibiotics against multidrug-resistant phenotypes. BMC Complement Altern Med 2011, 11:104.

7. Voukeng IK, Kuete V, Fankam AG, Dzoyem JP, Noumedem JAK, Kuiate J-R, Pages J-M: Antibacterial and antibiotic-potentiation activities of the methanol extract of some Cameroonian spices against Gram-negative multi-drug resistant Phenotypes. BMC Research Notes 2012, 5:299.

8. Lacmata ST, Kuete V, Dzoyem JP, Tankeo SB, Teke GN, Kuiate JR, Pages J-M: Antibacterial activities of selected Cameroonian plants and their synergistic effects with antibiotics against bacteria expressing MDR phenotypes. Evidence-Based Complementary and Alternative Medicine 2012, 2012:11.

9. Noumedem J, Mihasan M, Lacmata S, Stefan M, Kuiate J, Kuete V: Antibacterial activities of the methanol extracts of ten Cameroonian vegetables against Gram-negative multidrug-resistant bacteria. BMC Complement Altern Med 2013, 13:26.

10. Tanko Y, Yerima M, Mahdi MA, Yaro AH, Musa KY, Mohammed A: Hypoglycemic activity of methanolic stem bark of adansonnia digitata extract on blood glucose levels of streptozocin-induced diabetic wistar rats. International Journal of Applied Research in Natural Products 2008, 1:32-36

11. Kaboré D, Sawadogo-Lingani H, Diawara B, Compaoré CS, Dicko MH, Jakobsen M: A review of baobab (adansonia digitata) products: effect of processing techniques, medicinal properties and uses. African Journal of Food Science 2011, 5:833-844.

12. Yagoub S: Antimicrobial activity of Tamarindus indica and Adansonia digitata extracts against $E$. coli isolated from urine and water specimens. Research Journal of Microbiology 2008, 3:193-197.

13. Majorie MC: Plant product as antimicrobial agents. Clin Microbiol Rev 1999, 12:564-582.

14. Atawodi SE, Ameh DA, Ibrahim S, Andrew JN, Nzelibe HC, Onyike E, Anigo KM, Abu EA, James DB, Njoku GC, Sallau AB: Indigenous knowledge system for treatment of trypanosomiasis in Kaduna state of Nigeria. J Ethnopharmacol 2002, 79:279-282.

15. Doughari $\mathrm{JH}$ : Antimicrobial activity of Tamarindus indica Linn. Tropical Journal of Pharmaceutical Research 2006, 5:597-603. 
16. Abreu PM, Noronha RG: Volatile constituents of the rhizomes of Aframomum alboviolaceum (Ridley) K. Schum. from Guinea-Bissau. Flavour and Fragrance Journal 1997, 12:79-83.

17. Marlier M, Le Guellec G, Lognay G, Wathelet JP, Severin M: Characterization of three labdane diterpenes from Aframomum alboviolaceum. Planta Medica Paper Phytochemistry 1993, 455-457:59.

18. Kone WM, Atindehou KK, Dossahoua T, Betschart B: Anthelmintic activity of medicinal plants used in Northern Cote d'Ivoire against intestinal helminthiasis. Pharm Biol 2005, 43:72-78.

19. Ayafor JF, Tchuendem MHK, Nyasse B, Tillequin F, Anke H: Aframodial and other bioactive diterpenoids from Aframomum species. Pure Appl Chem 1994, 66:2327-2330

20. Thomas JMC, Bahuchet S, Epelboin A, Furnis S: Encyclopédie des Pygmées Aka: techniques, langage et société des chasseurs cueilleurs de la forêt centrafricaine(Sud-Centrafrique et Nord-Congo). Paris: Société d'études linguistiques et anthropologiques de France; 2003:11.

21. Noumi E, Eloumou MER: Syphilis ailment: prevalence and herbal remedies in ebolowa subdivision. South region, Cameroon. International Journal of Biomedical and Pharmaceutical Science 2011, 2:20-28.

22. Betti JL: An ethnobotanical study of medicinal plants among the baka pygmies in the Dja biosphere reserve, Cameroon. African Study Monographs 2004, 1-27:25.

23. Achenbach $\mathrm{H}$, Renner $\mathrm{C}$ : Constituents of West African medicinal plants. XVIII: the annonidines - a new class of prenylated bisindole alkaloids from Annonidium mannii. Heterocycles 1985, 23:2075-2081.

24. Olaleye MT: Cytotoxicity and antibacterial activity of methanolic extract of Hibiscus sabdariffa. Journal of Medicinal Plants Research 2007, 1:009-013.

25. Liu C-L, Wang J-M, Chu C-Y: In vivo protective effect of protocatechuic acid on tertbutyl hydroperoxide-induced rat hepatotoxicity. Food Chem Toxicol 2002, 40:635-641.

26. Lin WL, Hsieh YJ, Chou FP, Wang CJ, Cheng MJ, Tseng TH: Hibiscus protocatechuic acid inhibits lipopolysaccharide-induced rat hepatic damage. Arch Toxicol 2003, 77:42-47.

27. Kamali HHE, Mohammed MF: Antibacterial activity of Hibiscus sabdariffa, Acacia seyal var. seyal and Sphaeranthus suaveolens var. suaveolens against upper respiratory tract pathogens. Sudan Journal of Medical Sciences 2006, 2:121-126

28. Bruneton J: Plantes Médicinales, Pharmacognosie, Phytochimie. Paris: Tec et Doc; 1999

29. Ngassoum MB, Essia-Ngang JJ, Tatsadjieu LN, Jirovetz L, Buchbauer G, Adjoudjia O: Antimicrobial study of essential oils of Ocimum gratissimum leaves and Zanthoxylum xanthoxyloides fruits from Cameroon. Fitoterapia 2003, 74:284-287.

30. Pessoa LM, Morais SM, Bevilaqua CML, Luciano JHS: Anthelmintic activity of essential oil of Ocimum gratissimum Linn. and eugenol against Haemonchus contortus. Vetenary Parasitology 2002, 109:59-63.

31. Obinna NC, Nwodo CS, Olayinka AO, Chinwe IO, Kehinde OO: Antibacterial effects of extracts of Ocimum gratissimum and piper guineense on Escherichia coli and Staphylococcus aureus. African Journal of Food Science 2009, 3:077-081.

32. Escalona-Arranz JC, Péres-Roses R, Urdaneta-Laffita I, Camacho-Pozo MI, Rodríguez-Amado J, Licea-Jiménez I: Antimicrobial activity of extracts from Tamarindus indica L. leaves. Pharmacogn Mag 2010, 6:242-247.

33. Morton J: Tamarind in: fruits of warm climates. Miami, Fl, USA: Creative resources systems Inc.; 1987.

34. Harbone JB: Phytochemical methods: a guide to modern techniques of plant analysis. London: Chapman \& Hall; 1973.

35. Eloff JN: A sensitive and quick microplate method to determine the minimal inhibitory concentration of plant extracts for bacteria. Planta Med 1998, 64:711-713.

36. Kuete V, Ngameni B, Simo CCF, Tankeu RK, Ngadjui BT, Meyer JJM, Lall N Kuiate JR: Antimicrobial activity of the crude extracts and compounds from Ficus chlamydocarpa and Ficus cordata (Moraceae). J Ethnopharmacol 2008, 120:17-24.

37. Ghisalberti D, Masi M, Pagès J-M, Chevalier J: Chloramphenicol and expression of multidrug efflux pump in Enterobacter aerogenes. Biochem Biophys Res Commun 2005, 328:1113-1118.

38. Cowan MM: Plant products as antimicrobial agents. Clin Microbiol Rev 1999, 12:564-582.
39. Tane P, Tatsimo SD, Ayimele GA, Conolly JD: Bioactive metabolites from Afromomum species. In 11th NAPRECA Symposium Book of Proceedings. Antananarivo, Madagascar; 2005:214-223.

40. Akinmoladun AC, Ibukun EO, Afor E, Obuotor EM, Farombi EO: Phytochemical constituent and antioxidant activity of extract from the leaves of Ocimum gratissimum. Scientific Research and Essays 2007, 2:163-166.

doi:10.1186/1472-6882-13-164

Cite this article as: Djeussi et al:: Antibacterial activities of selected edible plants extracts against multidrug-resistant

Gram-negative bacteria. BMC Complementary and Alternative Medicine 2013 13:164

\section{Submit your next manuscript to BioMed Central and take full advantage of:}

- Convenient online submission

- Thorough peer review

- No space constraints or color figure charges

- Immediate publication on acceptance

- Inclusion in PubMed, CAS, Scopus and Google Scholar

- Research which is freely available for redistribution 